\title{
EVALUATION OF PROVIDING MILITARY SERVICE ORGANIZATIONS ECONOMIC PERFORMANCE BY EXECUTIVE DASHBOARDS
}

Marcelo David Davis State University of Rio de Janeiro. Senior Officer at Brazilian Navy, Brazil E-mail: marcelodavis@gmail.com

Esdras Carlos de Santana Federal University of Rio de Janeiro. Senior Officer at Brazilian Navy, Brazil E-mail: esdrascarlos@ig.com.br

Maria de Fátima Bandeira dos Santos Federal University of Rio de Janeiro. Senior Officer at Brazilian Navy, Brazil E-mail: mariafatimasanto@hotmail.com

Renato Santiago Quintal State University of Rio de Janeiro. Senior Officer at Brazilian Navy, Brazil E-mail: rsantiago79@hotmail.com

Jorge Luiz Tesch Santos Middle Officer at Brazilian Navy, Brazil E-mail: jorginhotesch@hotmail.com

Submission: $20 / 05 / 2016$ Revision: 03/06/2016 Accept: 10/06/2016

\section{ABSTRACT}

The subject of this article is to explore what are the possibilities and limitations of the use of a computerized system of executive dashboards to evaluate the providing military service organizations economic performance. This research is classified as qualitative, nonexperimental, exploratory, bibliographic, documentary and case study. The main findings are associated with the fact that the use panel indicators allowed for more accurate monitoring, and in the shortest time, the performance of these organizations; 
INDEPENDENT JOURNAL OF MANAGEMENT \& PRODUCTION (IJM\&P)

http://www.ijmp.jor.br

v. 7, n. 4, October - December 2016

ISSN: 2236-269X

DOI: 10.14807/ijmp.v7i4.484

viewing the most current and critical of their economic situation, allowing the identification and timely recommendations corrections; integration of information in a data platform safer; creating historical series for the preparation of studies and works with applications in Brazilian Navy and academia, and finally, facilitating the reading of the indicators for the use of new graphics and images in metrics representation.

Keywords: Public Management. Armed Forces. Management Control. Indicators. Efficiency

\section{INTRODUCTION}

Nowadays, as a result of developments throughout the twentieth century the concept of efficiency in public administration is closely related to the quality of service, as well as the optimization of use of public funds, passing even the expressly stated in the Republic Constitution with the Constitutional Amendment 19/98, known as Administrative Reform.

In this context, the Brazilian Navy Financial Directorship, as the Brazilian Navy Sector Accounting, envisioned the necessity to implement a corporate system for planning, evaluation and control of the providing military service organizations with the purpose of guiding and monitoring the performance of those organizations and improve the process of cost accounting.

Result of a partnership agreement between the Directorship and Alberto Luiz Coimbra Institute for Graduate Studies and Research in Engineering at Federal University of Rio de Janeiro, the system was developed Executive Dashboard, which access occurs in a virtual environment through the link provided in Directorship's webpage. This system comes with the fixed idea of ensuring that the information transmission is made in a more effective and organized way. In short terms, there is the prediction of the occurrence of initial spending on training programs for system operation. Next, it will be necessary the disclosure of the system functionalities, as well as the benefits of its use by the High Naval Administration.

The purpose of this paper is to verify what are the possibilities and limitations of the use of a computerized system of executive dashboards to evaluate the economic performance of providing military service organizations. The paper consists of the following sections: theoretical reference, research methodology, analysis and discussion, and closing remarks. 
INDEPENDENT JOURNAL OF MANAGEMENT \& PRODUCTION (IJM\&P)

http://www.ijmp.jor.br

v. 7, n. 4, October - December 2016

ISSN: 2236-269X

DOI: 10.14807/ijmp.v7i4.484

\section{THEORETICAL REFERENCES}

This section is divided into five subsections. The first will address the evolution of the state in the twentieth century; the second one will focus on the principle of efficiency in the public sector; the third will address the providing military service organizations systematic in the Brazilian Navy; the fourth will comment on the role played by the Brazilian Navy Financial Directorship in the control of these organizations; and last section will deal with the performance evaluation tools identified in the literature:

\subsection{The State evolution in the twentieth century}

A retrospective examination of the international monetary system after the Second World War shows that the Bretton Woods enabled the creation of an institutional arrangement which enabled an era of great prosperity of capitalism, in spite of leaning more to the American proposition. The Bretton Woods system led predictability to capitalists' decisions and made possible the achievement of extremely favorable economic results.

This was thus an international monetary arrangement that under American control allowed the reconstruction of European and Japanese industries, peripheral industrialization and development of independent national economies. In this context, it is worth nothing that without this monetary system hardly the golden age of capitalism would have occurred (OLIVEIRA; MAIA; MARIANO, 2008).

The heyday of post war and social democratic hegemony of 1960s in a form defined as Fordist production. Therefore, the crisis of social democracy in the 1970s was the materialization of the collapse of Fordism modes of regulation as a result of the crisis of Fordist production. It is necessary to emphasize that Fordism was based on the mass production of homogeneous products, using a rigid assembly line technology, with specialized machines and formatted working lines. Thus, it was possible to manage an increase in productivity through economies of scale, as well as the disqualification, work intensification and homogenization (CLARKE, 1991).

Throughout the first years after World War II, the States effectively programmed monetary and fiscal policies and positioned near full employment by more extensive time interval already hit by capitalist economies. Additionally, 
INDEPENDENT JOURNAL OF MANAGEMENT \& PRODUCTION (IJM\&P)

http://www.ijmp.jor.br

v. 7, n. 4, October - December 2016

ISSN: 2236-269X

DOI: 10.14807/ijmp.v7i4.484

prosperity related to sustained full employment was more widely shared throughout the population than in any previous boom phase.

The golden age of capitalism after World War II was based on a hegemonic position of the USA, which maintained their own economy close to full employment and allowed their trading partners reached considerable surpluses to offset, even partially, the incomes of USA's capital. This hegemonic position has been overthrown by the import policy in the setting of wars, armies based abroad and grant the defense efforts of others (MINSKY, 1994).

From the viewpoint of geopolitics of oil after Second World War, we observe three standards of international market regulation. The first one takes place from 1945 to 1973 and was characterized by the consolidation of U.S. hegemony in the Middle East and the market leadership of the major North American oil companies.

The second goes from 1973 to 1985 and had its beginning marked by the First Oil Crisis, characterized by disruption of the existing order for almost thirty years in the context of the impact of the international monetary system crisis post Bretton Woods and of the U.S. defeat in the Vietnam War, as well as failed attempts at reordering the market, especially the Iranian Revolution of 1979. Finally, since 1985, there is a new system of regulation of international oil market, characterized by its financing and a scenario marked by the resumption of American hegemony (TORRES FILHO, 2004).

In the 1970s, there was a transition of thirty golden years of capitalism (19481977) for capitalism led by financial sector. The golden era was characterized by regulated financial markets, financial stability, robust rates of economic growth and the reduction of inequality. In the years of neoliberalism was observed just the opposite: reduction of growth rates; rapid increase in financial instability and increased socioeconomic inequality.

The collapse of the Bretton Woods system, financing and conservative counter revolution promote a new economic arrangement. In the USA, with Ronald Reagan victory in the presidential elections, there was the rise to power of a political coalition advocate of neoliberalism. In the 1970s, neoclassical macroeconomics replaced the Keynesian and the models of growth replaced the development economics. 
INDEPENDENT JOURNAL OF MANAGEMENT \& PRODUCTION (IJM\&P)

http://www.ijmp.jor.br

v. 7, n. 4, October - December 2016

ISSN: 2236-269X

DOI: 10.14807/ijmp.v7i4.484

Neoclassical economists (Milton Friedman and Robert Lucas), from Austrian School (Friedrich Hayek) and the School of Public Choice (James Buchanan) gained influence and built neoliberal ideology from the foundations of the old ideas of laissez-faire and a mathematical economics which provided scientific legitimacy to the new creditor. Desiring explicitly reduce indirect salaries as from the flexibility of the ideas of labor protection. It was attempted to also decrease the size of the state apparatus and deregulate all markets, especially the financial (BRESSER-PEREIRA, 2010).

In November 1989, the United States capital hosted a meeting between officials of the USA government and international financial institutions based there International Monetary Fund, World Bank and Inter-American Development Bank specialized in Latin American area. The purpose of the meeting purpose was to conduct an assessment of the economic reforms implemented in the region. In order to reporting the experience of their countries, were also present distinct Latin American economists.

At the end of this meeting is that it would give, subsequently, the informal designation of "Washington Consensus". Despite the academic format and without deliberative essence, the meeting would allow the opportunity to coordinate actions by entities with a relevant role in these reforms. Therefore, despite its informal nature, would eventually have a symbolic significance, broader than many official meetings in regional multilateral forums.

The relevance of the Washington Consensus is the fact that aggregates, in an integrated set, sparse elements from different sources, sometimes directly from the U.S. government, at other times its agencies, the International Monetary Fund or the World Bank. It was not talked about new formulations in the Washington Consensus, but simply noted, with approval, the extent of the enforcement of policies already recommended, at different times, by different agencies (BATISTA, 1994).

With the advent of the Berlin Wall fall, there was brief reading of the meaning of the end of the cold war, noting in a precipitated form the emergence of new international order, an unquestionable Pax Americana, which would be inevitable adapt. It was accepted the triumph of the market economy and democracy (BATISTA, 1994). 
INDEPENDENT JOURNAL OF MANAGEMENT \& PRODUCTION (IJM\&P)

http://www.ijmp.jor.br

v. 7, n. 4, October - December 2016

ISSN: 2236-269X

DOI: 10.14807/ijmp.v7i4.484

In the early 2000s, new determinations of capitalism go to the deterioration of labor relations, in a capitalists' effort from to retain its profit rate, which are inserted in the midst of consolidation of neoliberalism as a theoretical and ideological framework of capitalist hegemony, manifesting in specific ways, seemingly unconnected to each other, but actually express the changes planned by capitalists to remain in the field of production process and social reproduction (CARVALHAL, 2001).

\subsection{The Principle of Efficiency in the Public Sector}

In this post-modern context, of privatization, State inefficiency, bureaucratization, arises Constitutional Amendment 19/98 bringing the principle of efficiency. This Amendment was responsible for the implementation of State Reform. According the teachings of Carvalho Filho (2012):

With the inclusion, the Government intends to confer rights to users of various services provided by the Administration or by private delegate and set effective obligations for service providers. It is not difficult to notice that the inclusion of this principle reveals the society discontent about his former impotence to fight against the poor performance of many public services, which uncountable loss already caused to the users. Indeed, such services being provided by the State or their private delegates, it was always inaccessible to the users effective ways to secure their rights. The few ones were insufficient or innocuous to solve the irregularities committed by the Government in execution of public services (CARVALHO FILHO, 2012, p.29).

With the democratization of the country, citizens increasingly begin to fight to see their rights effected, requiring the state that public services are provided with the utmost speed and efficiency. Di Pietro (2000) conceptualizes public service as: "all material activity that the law assigns to the State to exercise it directly or by private delegate, aiming to concretely satisfy the collective needs, under full or partial legal regime of public law". Thus is born the dogma of efficiency, bringing the question of whether such efficiency should really even be achieved at any cost. By appropriate, it should bring forth teachings Carvalho Filho (2012):

Efficiency is distinct from the efficacy and effectiveness. Efficiency transmits sense related to the way in which it processes the performance of administrative activity; the idea is related, thus, to agent conduct. On the other hand, efficacy is related with the means and instruments used by agents in the exercise of their duties in the administration; here the sense is typically instrumental. Finally, effectiveness is focused on the results obtained by the administrative actions; accentuate in this aspect the objectives positivity (CARVALHO FILHO, 2012, p.31). 
The above theme is very present in certain organs of the public sector where there is the idea of efficiency at any cost, where the public official is well rated if he can perform many procedures in a minimum of time. However, the doctrine ask yourself about the quality of care and if this efficiency would really be a dogma to be pursued at any cost.

Actually, what one wishes is just a quality in the State's response, an excellence in the provision of administrative function, which shows that the efficiency cannot be an absolute issue, because an analysis of other issues that are at stake is required along with the principle of efficiency.

And it is exactly this scope that characterizes the efficiency. The efficiency mentioned here means exactly the quality of service and is linked to the idea of economy of resources and time, as well as to optimize them.

\subsection{The providing military service organizations}

In the context of efficiency, in the mid-90s was deployed providing military service organizations systematic within the Brazilian Navy, system that had as its main function the control and measurement of the costs of these organizations (BRASIL, 2008).

At that time one had the following situation: a) constant financial deficits of these organizations; and b) lack of other economic and equity positions that enabled the identification and correct assessment of the various activities undertaken in these organizations (BRASIL, 2008).

Due to these factors, the need to create a system with the following characteristics emerged:

a) the effective notion of all operating expenses of these organizations, separated into direct and indirect costs production/service delivery, expenses generated by administrative activities, and losses; and

b) the assets control, in other words, perfect knowledge of financial resources, understanding of billings made and stocks turnover. The Brazilian Integrated Financial Administration System and Cost Accounting, by adopting the 
INDEPENDENT JOURNAL OF MANAGEMENT \& PRODUCTION (IJM\&P)

http://www.ijmp.jor.br

v. 7, n. 4, October - December 2016

ISSN: 2236-269X

DOI: 10.14807/ijmp.v7i4.484

absorption costing, were the tools chosen in order to make the operation of this new system.

The providing military service organizations system is characterized by their military organizations that provide services to other military organizations and occasionally to other institutions of public and private sectors in the following areas: industrial, scientific and technical, and hospital; charging the market price for services rendered, based on spending by it incurred (BRASIL, 2008).

It should be noted that these organizations are non-profit organizations, since this would represent an unnecessary encumbrance of their main "customers" that are own Brazilian Navy organs, earning just enough to cover their expenses, as stipulated in the internal Navy rules. Again, the caveat is that these organizations are authorized to charge the market price when contracted by entities outside the Navy.

The main obstacle encountered in the implementation of this system was the need for a change in organizational culture. It is incontestable that each change requires a certain time in order to break some paradigms and consolidate the new management culture.

Costs are management indicators that serve to point dysfunctions or evaluate activities. To keep an activity, it is necessary know all the values involved and that imply its maintenance and, for this reason, decide for its continuation or not. Undeniably, such a decision is not based solely on spending, but also for strategic reasons. On several occasions it becomes necessary to maintain certain organizations, or some sectors, even underfunded, due to its importance, which does not preclude the relentless pursuit of excellence in order to meet the efficiency and economy principles.

Periodically, Brazilian Navy Financial Directorship reforms visits to providing military service organizations. These visits enable finds that the main shortcomings are due to management problems, more specifically these organizations inability to delineate their production processes and improve them. This situation ends up being evidenced by the results achieved by these organizations, especially with regard to the aspects of productivity and quality of services.

Hence, it is imperative that providing military service organizations prioritizes the pursuit of management excellence, adopting measures that allow optimizing the 
INDEPENDENT JOURNAL OF MANAGEMENT \& PRODUCTION (IJM\&P)

http://www.ijmp.jor.br

v. 7, n. 4, October - December 2016

ISSN: 2236-269X

DOI: 10.14807/ijmp.v7i4.484

application of its human and material resources, measures that effectively lead to the production of a good financial and economic performance.

\subsection{The role of Brazilian Navy Financial Directorship in providing military service organizations control}

The Brazilian Navy Financial Directorship integrates the Internal Control System of the Brazilian Navy, and aims to manage the activities related to Financial Management, Accounting and Payment of Staff in Navy.

That Directorship, while Sectorial Organ of Accounting in Brazilian Navy, promotes technical guidance of providing military service organizations and seeks constantly updating rules governing the Cost Accounting in Navy, besides stimulating research issues that contribute to the improvement of that systematic.

In this context, that Directorship realized the growing need to implement an enterprise system for planning, evaluation and control of providing military service organizations aiding in the systematic evaluation of their performance and the generation of information for decision making of these organizations and consequently the Navy.

The proposed project implementation is consistent with the that Directorship strategic planning, which provides improvement of the existing planning methodology, evaluation and control of providing military service organizations aiming to guide and monitor the performance of those organizations and improve the cost accounting process. This proposal is consistent with the character finalistic efficiency control and administration of results - conferred by the Brazilian Federal Constitution of 1988 to the Public Administration.

\subsection{Performance Evaluation}

To defend the relevance of measuring organizational performance, Fernandes (2004) highlights three main reasons: (1) one can only manage what one can measure; (2) solely, financial indicators are not sufficient to supply managers with the information they need due to the fact that they are "historically oriented"; (3) the current environment requires a more complex and comprehensive database system than that is currently provided 
INDEPENDENT JOURNAL OF MANAGEMENT \& PRODUCTION (IJM\&P)

http://www.ijmp.jor.br

v. 7, n. 4, October - December 2016

ISSN: 2236-269X

DOI: 10.14807/ijmp.v7i4.484

According to Certo and Peter (1993), "process control is exercised by measuring, comparing the real with objectives and goals, and implementation of corrective actions when necessary". Such procedure aims to ensure that the company's evolution would be given as planned, and it would alert the managers for possible deviations from the predetermined path. The primary role of indicators in strategic management is to understand how the action plans are evolving and measure the results obtained by these elaborated plans to achieve each specific objective of the organization's strategic planning.

Thus, the performance evaluation can be envisioned as identification and measurement of the actions that the organization managers perform during a given period. Performance evaluation aims to diagnose and analyze the performance and indicators of an organization within a timeline. This assessment allows obtaining a more reliable feedback of reality to the organization leaders, based on solid and tangible information, assisting them in decision making.

\section{METHODOLOGY}

According to the nature of the data, this study is classified as qualitative. for the more general goals, it can be classified as exploratory, since it aims to provide greater familiarity with the problem in order to make it more explicit. The study also includes bibliographic and documentary research. Furthermore, the research can be classified as a case study. Data is collected from the Brazilian Navy Financial Directorship.

\section{ANALYSIS AND DISCUSSION}

Few (2006) analyzed different panels about various areas and made by different organizations and concluded that a dashboard is a display of information that is the most important and necessary to achieve one or more objectives, consolidated and arranged on a single screen so the information can be monitored at a glance.

The traditional reporting systems only serve as instruments for evaluating historical facts, which is accomplished through comparative tables between what is planned and the actual results. The Executive Dashboard system provides a pictorial representation of business performance across the organization, allowing summary in only one page, large volumes of data very succinctly, and enabling managers to 
INDEPENDENT JOURNAL OF MANAGEMENT \& PRODUCTION (IJM\&P)

http://www.ijmp.jor.br

v. 7, n. 4, October - December 2016

ISSN: 2236-269X

DOI: 10.14807/ijmp.v7i4.484

compare results and make decisions more accurately and quickly of the company situation, representing a valuable tool since planning up to evaluation of results achieved. The Executive Dashboard is a set of indicators presented with optimized view over the entire management of an organization.

This is a tool designed to be a great facilitator of decision making. It was created to enable managers to have access systematically the most relevant information on organizational performance of an institution, i.e., the history of its activity. All the information that is stored in the databases of the organization does not have much use if you do not know how to present it to the respective decision makers of the institution.

Dashboards provide immediate information about business performance across the organization, generated for managers and executives who need an overview of the business and consider paramount to have an intuitive and timely view of the strategic, financial, and operational data. They can easily emphasize areas with low performance, because dashboards are modular, being, also, possible to compare dates and different sectors and make decisions about them quickly, without the necessity to flip through unreasonable amounts of reports.

Thus, the dashboard is a computerized system that allow monitoring of the providing military service organizations economic performance, through the transformation of the indicators in charts and graphs generated from information from, mostly, from management accounting and Brazilian Integrated Financial Administration System in a single document.

There are some great advantages in using dashboards: monitor the performance of the leading indicators; promote information visualization in a intelligent way; conquering the recipients to the monitoring process; increase transparency in the reporting of results; increase the audience with internal performance access; simplify the process of monitoring, besides being relatively inexpensive method.

There are several benefits associated with systematic communication of the results obtained during a certain period of time, nevertheless they are global or simply results from an organic unity. 
INDEPENDENT JOURNAL OF MANAGEMENT \& PRODUCTION (IJM\&P)

http://www.ijmp.jor.br

v. 7, n. 4, October - December 2016

ISSN: 2236-269X

DOI: 10.14807/ijmp.v7i4.484

The dashboard is responsible for disseminating the main indicators of the organization, which is done quite succinctly, usually in only one page. Being a limited space requires that, in its parameterization, the organization must be able to select the main information of the secondary. - don't understand the sentence

However, the indicators set selection that will configure the dashboard to the detriment of others does not mean that they will be summarily discarded. There may be several dashboards at different levels of information depth.

Whenever an organization prepares this task, there is a large array of information that is considered essential and therefore must appear in the dashboard. Only after the execution the user can check if the dashboard already contains all the necessary information, if it can still get more information or if, instead, already has more information than necessary.

The dashboard has a great concern of certifying that the transfer of the information to be placed in the most effective way as possible. It's effectiveness is not only to ensure that the final recipient would be able to have clear and immediate access to information. It is also important that the information is organized in a coherent way, exposing the most relevant aspects and relating data to allow consistent analyzes, so that the manager be able to obtain information essential to the identification of more efficient actions.

At the opposite extreme to the dashboard are the traditional reports, extensive, with too much information, unable to communicate and transfer clear and fast the information which the manager needs. Beforehand, the report's recipient knows that will have to spend considerable time in order to analyze and subsequently get to take a decision based on this document, that is, know that he can hardly, within minutes, get a clear, objective and integrated point of situation.

The application of dashboard design is clearly a critical success factor, both to enhance the effectiveness of communication both to captivate recipients to use this tool. The design is responsible for giving to the dashboard simplicity, clarity and elegance. These are significant aspects for the dashboard be a tool capable of grabbing the attention of potential users. Furthermore, there are other factors that contribute to its acceptance as the inclusion of information that really interests to 
INDEPENDENT JOURNAL OF MANAGEMENT \& PRODUCTION (IJM\&P)

http://www.ijmp.jor.br

v. 7, n. 4, October - December 2016

ISSN: 2236-269X

DOI: 10.14807/ijmp.v7i4.484

users, allowing them to be increasingly able to take timely and consistent decisions about the situation with the organization in real time.

Within the Navy, are glimpsed as key benefits: (1) more accurate monitoring, and in a shorter time, of providing military service organizations performance; (2) visualization most current and critical of these organizations Economic situation, enabling identification and timely recommendations for corrections; (3) integration of information in a more secure data platform; (4) creation of historical series for preparation of studies and works with applications in Navy and academia; and (5) facilitation the reading of indicators for the use of new graphics and images in the representation of the metrics.

Ahead of accomplishment of the computerized system, data extraction was performed by analysts, who extracted and manually put them in excel spreadsheets. With the advent of this joint research work, the system automatically performs the extraction of these data from Brazilian Integrated Financial Administration System in ".txt" files, and promotes direct sending to your database, minimizing the occurrence of errors and optimizing the work and time spent on this task, besides being a data platform endowed with greater security. Ultimately, it is planned to establish a pattern of management and performance analysis to ensure homogeneity in the overall treatment of information necessary for the making of rules and standards more reliable analysis to Brazilian Navy (QUINTAL; SANTOS; DAVIS; SANTANA; SANTOS, 2014).

The require of a corporate model for performance analysis, compelled Brazilian Navy Financial Directorship to attempt a model that could be deployed and used internally and afterwards employed in other Brazilian Navy Specialized Directorships. The formalization of the partnership with Alberto Luiz Coimbra Institute for Graduate Studies and Research in Engineering at Federal University of Rio de Janeiro enabled the consolidation of a standard of management and performance analysis to assure homogeneity in the overall treatment of information necessary for the formulation of rules and standards more reliable analysis to Brazilian Navy (QUINTAL; SANTOS; DAVIS; SANTANA; SANTOS, 2014).

Consequently, the implementation of a standardized approach of controlling internal processes culminated in the development of a model of management 
INDEPENDENT JOURNAL OF MANAGEMENT \& PRODUCTION (IJM\&P)

http://www.ijmp.jor.br

v. 7, n. 4, October - December 2016

ISSN: 2236-269X

DOI: 10.14807/ijmp.v7i4.484

information provided with quality and reliability, following from the use of modern techniques of extraction, processing and storage of data (QUINTAL; SANTOS; DAVIS; SANTANA; SANTOS, 2014).

This process aims to meet the changing needs of the population, as explained in Section 2.2 of this paper, for new quality services and transparent provided by the Government, result of an entire political developments in contemporary society.

\section{CLOSING REMARKS}

The purpose of this paper is to verify what are the possibilities and limitations of a computerized system of executive dashboards application to evaluate the economic performance of RMOS. To conduct this study, reports and other documents components of physical and digital collections of Brazilian Navy Financial Directorship were accessed, especially those related to Rendering Military Organizations of Services (RMOS) managed by that Sector

The results show a significant improvement in the information quality, especially those relating to the monitoring of information, the visualization of the economic-financial situation of the organizations supported, the integration of information, and the establishment of a historical series. These are functionalities that enable the provision of a better service to organizations, as well as to provide the population information with greater transparency about the quality of public spending on these activities.

This research has limitations related to the fact the search results are restricted exclusively to the case studied, being impossible to generalize with government other organs of, which would require specific monitoring and evaluation of those organizations. This fact does not preclude future research and it could be recommended in other organs of government in order to assess the level of acceptability of data generated by computerized systems of this nature by the decision makers of those organs.

\section{ACKNOWLEDGMENT}

The authors thank the illustrious referee of the Independent Journal of Management \& Production by the criticisms and suggestions made to the text of the original version. 
INDEPENDENT JOURNAL OF MANAGEMENT \& PRODUCTION (IJM\&P)

http://www.ijmp.jor.br

v. 7, n. 4, October - December 2016

ISSN: 2236-269X

DOI: 10.14807/ijmp.v7i4.484

\section{REFERENCES}

BATISTA, P. (1994). Consenso de Washington. Caderno da Dívida Externa $\mathbf{n}^{\circ} 6$. São Paulo: Gráfica e Editora Peres Ltda.

BRASIL. (2008). Marinha do Brasil. Secretaria Geral da Marinha. SGM-304: Normas sobre Contabilidade das Organizações Militares Prestadoras de Serviços. Brasília, 2008.

BRESSER-PEREIRA, L. (2010). A crise financeira global e depois: um novo capitalismo? Novos estudos. CEBRAP, São Paulo, n. 86. Available at $<$ http://www.scielo.br/scielo.php?script=sci_arttext\&pid=S0101$33002010000100003 \&$ lng=en\&nrm=iso>. Acesso em 19 de dezembro de 2013. http://dx.doi.org/10.1590/S0101-33002010000100003.

CALDEIRA, J. Dashboard: Comunicar Eficazmente a Informação da Gestão. Coimbra: Edições Almedina, 2010.

CARVALHAL, M. (2001). O engendramento da crise do capital nas redefinições do mundo do trabalho e na reconfiguração territorial. Pegada (UNESP. Impresso), Presidente Prudente, v. 2, n. 2, p. 21-34.

CARVALHO FILHO, J. (2012). Manual de direito administrativo. 25a ed. São Paulo: Editora Atlas.

CERTO, S.; PETER, J. (1993). Administração estratégica: planejamento e implementação da estratégia. São Paulo: Makron Books.

CLARKE, S. (1991). Crise do fordismo ou crise da social-democracia? Lua Nova, São Paulo, n. 24. Available at

<http://www.scielo.br/scielo.php?script=sci_arttext\&pid=S0102-

64451991000200007\&lng=en\&nrm=iso>. Accessed on December 19, 2013. http://dx.doi.org/10.1590/S0102-64451991000200007.

DI PIETRO, M. (2000). Direito Administrativo. 12a ed. São Paulo: Editora Atlas.

FERNANDES, B. (2004). Competências e performance organizacional: um estudo empírico, PhD Thesis, São Paulo: Faculdade de Economia, Ciências Contábeis e Administração da Universidade de São Paulo.

FEW, S. (2006). Information Dashboard Design, O`Relly, Sebastopol.

MINSKY, H. (1994). Integração financeira e política monetária. Economia e Sociedade, Campinas, n. 3.

OLIVEIRA, G.; MAIA, G.; MARIANO, J. (2008). O sistema de Bretton Woods e a dinâmica do sistema monetário internacional contemporâneo. Pesquisa \& Debate (Online), v. 34, p. 195-219.

QUINTAL, R., SANTOS, J. , DAVIS, M., SANTANA, E. , SANTOS, M. (2014). Endeavor in Management Process by Executive Dashboards: The Case of the Financial Directorship in Brazilian Navy. World Academy of Science, Engineering and Technology, International Science Index 90, International Journal of Social, Behavioral, Educational, Economic, Business and Industrial Engineering, v. 8, n. 6, p. 1689-1693. 
ISSN: 2236-269X

DOI: 10.14807/ijmp.v7i4.484

TORRES FILHO, E. (2004). O Papel do Petróleo na Geopolítica Americana. In: José Luís Fiori. (Org.). O Poder Americano. Petrópolis: Vozes, p. 309-346. 